\title{
Enabling Flexible Polymer Tandem Solar Cells by 3D Ptychographic Imaging
}

Dam, Henrik Friis; Andersen, Thomas Rieks; Pedersen, Emil Bøje Lind; Thydén, Karl Tor Sune;

Helgesen, Martin; Carlé, Jon Eggert; Jørgensen, Peter Stanley; Reinhardt, Juliane ; Søndergaard, Roar R.; Jørgensen, Mikkel; Bundgaard, Eva; Krebs, Frederik C; Andreasen, Jens Wenzel

Published in:

Advanced Energy Materials

DOI:

10.1002/aenm.201400736

Publication date:

2015

Document Version

Peer reviewed version

Link to publication

Citation (APA):

Dam, H. F., Andersen, T. R., Pedersen, E. B. L., Thydén, K. T. S., Helgesen, M., Carlé, J. E., ... Andreasen, J. W. (2015). Enabling Flexible Polymer Tandem Solar Cells by 3D Ptychographic Imaging. Advanced Energy Materials, 5(1), [1400736]. 10.1002/aenm.201400736

- You may freely distribute the URL identifying the publication in the public portal ? 


\section{WILEY-VCH}

DOI: 10.1002/ ((please add manuscript number))

\section{Article type: Full Paper}

\section{Enabling Flexible Polymer Tandem Solar Cells by 3D Ptychographic}

\section{Imaging}

Henrik F. Dam, ${ }^{a}$ Thomas R. Andersen, ${ }^{a}$ Emil B. L. Pedersen, ${ }^{a}$ Karl T. S. Thydén, ${ }^{a}$ Martin

Helgesen, ${ }^{a}$ Jon E. Carlé, ${ }^{a}$ Peter S. Jørgensen, ${ }^{a}$ Juliane Reinhardt, ${ }^{b}$ Roar R. Søndergaard, ${ }^{a}$ Mikkel Jørgensen, ${ }^{a}$ Eva Bundgaard, ${ }^{a}$ Frederik C. Krebs, ${ }^{a}$ and Jens W. Andreasen ${ }^{a^{*}}$

Dr. H. F. Dam, Dr. T. R. Andersen, E. B. L. Pedersen, Dr. K. T. S. Thydén,Dr. M. Helgesen, Dr. J. E. Carlé, Dr. P. S. Jørgensen, Dr. R. R. Søndergaard, Dr. M. Jørgensen, Dr. E. Bundgaard, Prof. F. C. Krebs, Dr. J. W. Andreasen

Department of Energy Conversion and Storage, Technical University of Denmark, Frederiksborgvej 399, DK-4000 Roskilde, Denmark

Email : jewa@dtu.dk

J. Reinhardt

Deutsches Elektronen-Synchrotron DESY, D-22607 Hamburg, Germany

Abstract: The realization of a complete tandem polymer solar cell under ambient conditions using only printing and coating methods on a flexible substrate comprises a fully scalable 


\section{WILEY-VCH}

process but also requires accurate control during layer formation to succeed. The serial process where one layer is added one after the other by wet processing leaves plenty of room for error and the process development calls for an analytical technique that enables 3-dimensional reconstruction of the layer stack with the possibility to probe thickness, density and chemistry of the individual layers in the stack. We present the use of ptychography on a complete 12layer solar cell stack and show how this technique provides the necessary insight to enable efficient development of inks and processes for the most critical layers in the tandem stack such as the recombination layer where solvent penetration in fully solution processed 12-layer stacks is critical in eleven of the steps.

Keywords: tandem solar cell, X-ray phase contrast, multilayer, ITO free, ptychography.

\section{Introduction}

Functionality of wet processed organic/inorganic multilayer stacks delicately relies on the quality of the individual layers in the stack and the robustness of previously processed layers to subsequently processed layers. The most extreme case is the fully wet processed polymer tandem solar cell that may comprise as many as $12-14$ layers. ${ }^{[1]}$ A defect in just one of the interfaces may completely overthrow the device functionality and lead to failure. Finding the cause for the failure requires nanoscopic insight into the sample itself. A laboratory study of a sub-set of the layers might be useful but the ultimate technique must encompass the possibility for detailed analysis of the entire stack in both its functional and non-functional form. Ideally the technique enables a complete 3-dimensional reconstruction of the sample with detailed insight into the thickness and chemistry of the individual layers of the stack. In 


\section{WILEY-VCH}

addition to the analytical technique, several other tools must be developed or tailored to fit the purpose of studying film formation and extraction of unscathed excerpts from the multilayer stack for analysis.

The solution processed polymer and organic solar cell is a very good example of a device where functionality is deeply rooted in the stacking of layers with the multijunction organic solar cell representing the ultimate case. The field of organic solar cells has to a large extent been based upon the vision of fast production of large areas of solar cells at very low cost. One of the means envisaged to achieve this is roll-to-roll (R2R) solution processing on flexible substrates. This has also been demonstrated although there is a large gap between the performance reached for very small area devices and devices with a practical size of square meters or more. The scalability has however been proven in a recent study where it was shown that serial connection on the $\mathrm{km}$ scale at total processing speeds in the $\mathrm{m} \mathrm{min}^{-1}$ range for finished and laminated cells ${ }^{[2]}$ was possible, allowing up to $10 \mathrm{kV}$ from a $100 \mathrm{~m}$ long module with full scaling of the power extraction. The fact that samples of organic solar cell modules $\left(10 \times 14.2 \mathrm{~cm}^{2}\right)$ can be acquired by anyone free of charge ${ }^{[3,4]}$ also illustrates a cost level approaching what was originally envisaged. The low cost has been achieved through use of the previously reported Flextrode substrate ${ }^{[2,5]}$ dispensing with the otherwise commonly employed indium tin oxide electrode (ITO), accompanied by careful optimization of the process conditions using tools such as life cycle analysis ${ }^{[6]}$ to bring down the amount of material and energy used in the process.

However, the performance of the organic solar cell is still not at the desired level. Although efficiencies of up to $12 \%$ have been achieved for small scale laboratory devices ${ }^{[7-11]}$, these results have been obtained using rigid glass substrates, expensive and scarce ITO for the transparent electrode and by use of processing methods which are not directly transferable to 


\section{WILEY-VCH}

large scale production. For R2R processed solar cells on flexible substrates the performance is in the $2-4 \%$ range $^{[12]}$ for large area devices - a consequence of the difficulties involved in the precise processing of a multilayer stack on a flexible, moving substrate.

One way to increase the efficiency of solar cells is to use complementary light absorbing materials, each absorbing a specific part of the solar spectrum, working in tandem as a multi-junction. ${ }^{[13-15]}$ This allows for absorption of a broader part of the solar spectrum and in theory a larger conversion efficiency, but also requires current matching of the different junctions as well as a demand for efficient recombination layers between the sub-cells. The recombination layers must act both as charge selective layers in the individual junctions as well as good media for combining opposing charges from the adjacent junctions in order to minimize current loss. Polymer tandem solar cells have been reported on several occasions but only very few have been using R2R or R2R compatible processing. ${ }^{[16-19]}$ Polymer tandem solar cells often consist of 10-14 distinct layers, all of which have to be continuous and homogeneous in thickness. Especially on flexible substrates this constitutes an enormous challenge as each layer should not only be processed with high accuracy and uniformity, but are also required to be able to sustain subsequent flexing. Andersen et al. recently demonstrated such roll-coated architecture achieving 1.3\% efficiency using double sided illumination of a flexible P3HT:PCBM|P3HT:PCBM tandem cell ${ }^{[18]}$ and although this is an impressive result on a flexible substrate the double junction did not exceed the single junction with respect to efficiency which is the primary goal of tandem cells and it was clear that more powerful techniques were needed for the process and stack development.

In this report we present the use of in situ X-ray structural characterization during coating, excerption of the entire multilayer stack using Focused Ion Beam milling (FIB) and high resolution X-ray phase contrast imaging (known as ptychography) of 12-layer polymer 


\section{WILEY-VCH}

tandem solar cells on flexible ITO-free substrates using complementary low and high band gap polymers. The methodology allowed us to efficiently develop the coating and drying process for each layer thus enabling successful wet processing under ambient conditions of all layers yielding large area flexible tandem solar cells.

\section{Results and Discussion}

\subsection{Roll processing and roll-2-roll analysis}

First attempts at roll processing of the complete tandem solar cell stack on flexible substrates proved unsuccessful, with solar cells functioning as single junctions as result. Visual inspection during coating gave indications that the integrity of the recombination layer might be compromised during coating by solvent penetration from the overlying layers. To overcome this problem, we needed to develop the process for the multilayer stack and an analytical technique enabling careful study of the film formation while in progress. Until now, most studies on films for organic electronics are studies ex situ such that the relevant film or interface is created in an experimental setup where the study is possible. This reductionistic approach proved to be insufficient in our case and we had to develop a small R2R coating machine such that the mechanism of multilayer film formation could be studied in situ using X-rays during deposition of one layer on top of the next. This was realized by further development of a previously developed R2R X-ray scattering apparatus $^{[20]}$ such that it was possible to actually coat the film and study it using X-ray scattering while drying as shown in Figure 1. The small R2R coater was integrated with a Grazing Incidence Small Angle X-ray Scattering (GISAXS) system and used to analyze the crystallinity of a P3HT:PCBM bottom cell during coating of the different layers of the stack. The use of an R2R setup lies with the need to identify the crystallinity of the bottom cell, 


\section{WILEY-VCH}

while being subjected to solvent. The assumption was that the crystallinity of the bottom cell would be affected by solvation during coating, if solvent penetrated the recombination layer. Therefore, GISAXS patterns of each layer were obtained in situ during coating conducted at a controlled distance from the X-ray probe point, allowing measurement at a position with a constant wet-layer thickness.

We found that we could detect the crystalline signal (100 reflection) from the lamellar stacking of P3HT in the P3HT:PCBM sub-cell during coating, at a position just after the drying front of the film (bottom left in Figure 1). The signal could still be distinguished during coating of the recombination layer consisting of PEDOT:PSS F40 (second from left) and $\mathrm{ZnO}$ (middle), with the latter also giving a very strong small angle scattering contribution because of the nano-crystalline structure. However, with the coating of the second sub-cell from chlorobenzene (second from right in Figure 1), the intermediate layer was clearly solvent saturated as evidenced by the reduction in small angle scattering intensity from the porous $\mathrm{ZnO}$ layer, now completely penetrated by solvent, and the concomitant disappearing of the 100 reflection from P3HT because of solvation. The P3HT recrystallizes with evaporation of the chlorobenzene, but redistribution of material throughout the recombination layer, surely leads to device failure. By coating the stack with a layer of butanol, which is not a solvent for the underlying layers, we tested that the elimination of P3HT diffraction is not due to the presence of a wet layer alone (bottom right in Figure 1).

Having established the catastrophic failure mechanism by solvent penetration during coating, we proceeded to investigate potential improvements of the solvent resistance of the intermediate recombination layer. One of the most challenging parts of manufacturing multilayer coated devices using only wet processing lies with the ability to keep the individual 


\section{WILEY-VCH}

layers separate. Moreover, keeping the layers thin enough to allow a high transparency and a good conductivity and still using optimal solvent combinations for the active layer blends for both top and bottom sub cells in a tandem stack, increases the difficulty further. Experiments with an additional Clevious P VP AL 4083 PEDOT:PSS layer succeeded, yielding functional tandem solar cell stacks on a flexible substrate. This combination using two PEDOT:PSS types and a zinc oxide layer as a recombination layer presumably has a better solvent resistance, allowing the fabrication of working tandem cells, while keeping the optical and electrical performance high. This intermediate layer, together with a range of other combinations were previously reported, ${ }^{[18]}$ however with homo-cell tandem devices, illuminated from both front and bottom side, leading to the transparency of the recombination layer not being probed. Herein we demonstrate the performance which can be achieved with single sided illumination, where the true nature of the tandem cell is employed, with the high band gap front cell absorbing the high energy photons and the low band gap back cell absorbing the low energy photons, using only R2R compatible methods and materials. One of these cells was analyzed by high resolution X-ray phase contrast imaging, as discussed below.

\subsection{Ptychographic X-ray imaging of a multilayer stack}

Ptychography was developed for electron diffraction by Hoppe in $1969^{[21-23]}$ as a method for improving spatial resolution beyond the limitations of probe size, and has subsequently been adapted for visible light ${ }^{[24]}$ and X-ray microscopy. ${ }^{[25]}$ The principle of ptychography is to collect the far-field diffraction patterns from the sample, illuminated by a localized coherent probe in a large number of overlapping steps, thus introducing a redundancy in the data set by oversampling, which is exploited to recover the phase information by iterative algorithms. Since the first theoretical work of Hoppe, the practical implementations awaited 


\section{WILEY-VCH}

solutions to the computational problems of collecting, handling and analysing the large volumes of data that are required. ${ }^{[26,27]}$ With this method, we obtain the complex-valued projections of phase shifts through an extended sample, i.e. the usual requirement of coherent diffractive imaging that the entire sample is illuminated by the coherent beam, is lifted. By combining phase projections from different angles, we obtain the threedimensional distribution of X-ray refractive indices which is directly related to electron density. ${ }^{[28]}$ After the first practical demonstrations with hard X-rays, the development has been rapid and widespread and the technique is now available at many synchrotron beam lines. The penetration of hard X-rays allows a versatility of the technique that lends itself to material science while providing the capability for 3D imaging at very high spatial resolution $^{[29]}$ and the first applications in this field has recently appeared. ${ }^{[30,31]}$

Sample preparation is critical for the success of the approach and today it is possible to robustly make excerpts from a flexible organic film using FIB. Because of the small spatial extent $(250 \mathrm{~nm})$ of the highly coherent X-ray beam used for ptychographic illumination, ${ }^{[32]}$ the sample must be relatively small to avoid exceedingly long data acquisition time for the many overlapping projections. The FIB technique allows the preparation of a sample prism, cut out from the actual completed solar cell, of a few microns in side length, ideal for 3D imaging. The sample can be manipulated in the FIB microscope and fixed to a macroscopic sample holder for tomography. The functional tandem solar cell devices were prepared on a previously reported mini roll coater. ${ }^{[33,34]}$

X-ray ptychographic tomography were performed on a sample of the tandem cell stack to resolve the many layers of the tandem cell stack and confirm the limited mixing between the individually coated layers. The use of the X-ray ptychography technique allowed a high spatial resolution of the layers, as seen by the reconstructed projection shown in Figure 2A. 


\section{WILEY-VCH}

This powerful analytical tool combined with the in situ analysis of the film formation using GISAXS was thus used to develop the process of the full coated and printed organic tandem solar cells comprising 12 layers (Figure 2B). The good performance of the device, based on

the Flextrode substrate ${ }^{[5]}$ is remarkable, considering the highly porous structure of the silver front electrode (Figure 2C). The 3D analysis shows however, that the structure is efficiently filled by rotary screen printed PEDOT:PSS, forming a smooth surface for the coating of the subsequent layers (Figure 2C,D).

The materials used in these studies for tandem preparation and analysis (Figure $\mathbf{3 A}$ ) are the high band gap polymer $\mathbf{P 1}$ and the low band gap polymer $\mathbf{P 2}$ together with the acceptor molecule PCBM. The polymers $\mathbf{P 1}$ and $\mathbf{P} 2$ have an optical band gap of $1.97 \mathrm{eV}$ and $1.45 \mathrm{eV}$, respectively. Because the transmission of the Flextrode substrate is lower for the longer wavelength light (Figure 3C,D), the optimum band gap combination, as described by Ameri et al., is moved, requiring either a higher high band gap material or a tailoring of the high band gap sub-cell thickness.

\subsection{Device performance}

The performance of the tandem cells presented herein (Figure 3B) shows a high efficiency when compared to the efficiency of the produced single junction reference cells based on the two polymers used as high and low band gap sub-cells. The efficiency may seem low compared to the present $11-12 \%$ records for the OPV field, ${ }^{[11]}$ however taking into account the scalable fabrication methods used, the $2.67 \%$ efficiency of the tandem cell is indeed very satisfactory. Even more so, because the device is made on a flexible substrate, which as 
shown previously leads to a reduced light intensity reaching the active layer and thereby a reduced maximum efficiency.

Considering the performance parameters of the tandem cell, the combination of the two sub cells shows an open circuit voltage of $1.32 \mathrm{~V}$, which compared to the sum of the reference cells of $1.44 \mathrm{~V}$ is a reduction of $8.3 \%$. The maximum current output of the solar cell is reduced from $5.4 \mathrm{~mA} / \mathrm{cm}^{2}$ and $4.9 \mathrm{~mA} / \mathrm{cm}^{2}$ for the individual reference cells to $4.3 \mathrm{~mA} / \mathrm{cm}^{2}$ for the tandem cell. This compares well with maximum theoretical current for a tandem cell being limited by current matching of the individual cells causing the tandem cell in this case to be limited by the low band gap cell, with a further small loss due to the overlapping between the absorption spectrum of the two polymers. The small drop in voltage and current is a confirmation of the electrical function of the intermediate layer, while all the cells tested showed a performance ranging from $2.4 \%$ to $2.67 \%$ indicating a strong reproducibility and solvent resistance quality in the coated stack. In total 60 cells were coated, with $10 \%$ of the cells tested. The tested cells were chosen evenly along the coated stripe to sample the performance within the full batch.

\section{Conclusion}

A fully roll coated tandem polymer solar cell has been shown, fabricated using only large scale compatible processes on flexible substrate and with a performance which surpasses the performance of the reference cells produced from the individual polymers. We showed with in situ X-ray structural characterization of the coating process that the exact formulation of the intermediate recombination layer is critical for preserving the structural integrity of the bottom sub cell and thus the performance of the device. The successful formation of all the layers was documented with high resolution X-ray phase contrast imaging of the completed multilayer stack. 


\section{WILEY-VCH}

\section{Experimental}

\subsection{Materials used}

P3HT and PCBM were purchased from Plextronic and Merck or Solenne BV., respectively. $\mathbf{P 1}$ and P2 were synthesized in house via Stille coupling by known routes of synthesis first reported by Hou et al. ${ }^{[35]}$ and Carlé et al. ${ }^{[36]}$. PEDOT:PSS Clevious P VP AL 4083 and PEDOT:PSS Clevious F010 were purchased from Heraeus Materials GmbH.

\subsection{Inks}

Inks for the polymer blends were made by mixing polymer and PCBM and adding solvents. P1:PCBM ink was made in a 5:10 $\mathrm{mg} \mathrm{ml}^{-1}$ solution of chlorobenzene for tandem coating and 8:16 $\mathrm{mg} / \mathrm{ml}$ for reference cells. P2:PCBM ink was made in a 8:12 $\mathrm{mg} \mathrm{ml}^{-1}$ solution of chloroform for tandem coating and 16:24 $\mathrm{mg} \mathrm{ml}^{-1}$ for reference cells. PEDOT:PSS 4083 was mixed with isopropanol in a 1:2 volume ratio. F010 used as compatibilizer for PEDOT:PSS 4083 was mixed with isopropanol in a 1:4 volume ratio (and referred to as F40 in the text) and F010 used as hole conducting electrode was mixed with isopropanol in a 2:1 volume ratio (referred to as F20). Zinc Oxide ( $\mathrm{ZnO}$ ) ink was prepared as described in Hagemann et $a^{[37]}$

\subsection{Device Fabrication}

Tandem cell devices were fabricated on preprinted Flextrode substrate, with a series of coatings consisting of (1) front cell (high-bandgap) coated from P1 ink at $13 \mu \mathrm{m}$ wet layer thickness (2) PEDOT:PSS F40 wetting layer ink at $8 \mu \mathrm{m}$ wet layer thickness (3) PEDOT:PSS 4083 hole selective layer at $23 \mu \mathrm{m}$ wet layer thickness (4) Zinc oxide layer at 5 $\mu \mathrm{m}$ wet layer thickness (5) back cell (low-bandgap) P2 ink at $15 \mu \mathrm{m}$ wet layer thickness. The cells were completed with (6) PEDOT:PSS F40 wetting layer ink at $8 \mu \mathrm{m}$ wet layer 


\section{WILEY-VCH}

thickness, (7) PEDOT:PSS 4083 hole selective layer at $23 \mu \mathrm{m}$ wet layer thickness, (8) PEDOT:PSS F20 top electrode with a wet thickness of $38 \mu \mathrm{m}$, and (9) silver top electrode flexographically printed with a web speed of $1.3 \mathrm{~m} \mathrm{~min}^{-1}$. A full table of coating parameters and estimated dry thicknesses can be found in the Supporting Information, together with images of the cells from front and rear.

Reference single junction cells were fabricated using similar conditions, with the Flextrode substrate and a wet layer coating thickness of $14 \mu \mathrm{m}$ and $12 \mu \mathrm{m}$ for $\mathbf{P 1}$ and $\mathbf{P 2}$, respectively. After coating of the active layer, the cell was finished with layers 6-9.

\subsection{X-ray scattering experiments}

In situ small angle X-ray scattering (SAXS) experiments during coating of the device layers were carried out on a custom SAXS setup, using a rotating anode as source, operated at 40 $\mathrm{kV}, 40 \mathrm{~mA}$ in fine focus (200 $\mu \mathrm{m}$ source size), focused and monochromatized (wavelength $1.5418 \AA$ ) by a 2D multilayer, and collimated by 3 pinholes to a $1 \mathrm{~mm}$ beam diameter at the sample. The sample was illuminated at a position close to the drying front in a series of 100 $\mathrm{s}$ exposures while the substrate was moved from one roll to the other at a speed of $0.5 \mathrm{~m}$ $\min ^{-1}$, at $0.35^{\circ} \mathrm{X}$-ray incidence angle. The SAXS data were acquired with a $2 \mathrm{D}$ delay line gas proportional detector. ${ }^{[38]}$

For the ptychographic imaging, experiments were conducted at the P06 beam line at PETRA III in Hamburg with an intensity of $8 * 10^{6}$ photons s${ }^{-1}$ in a $250 \mathrm{~nm}$ beam, focused by silicon nano-focusing lenses ${ }^{[39]}$ with a $2.0 \mathrm{~m}$ sample-detector distance. Ptychography projections were taken at 90 projections over $180^{\circ}$ projection angles with a 4.1 x $1.8 \mu \mathrm{m}$ field of view and an approximately 22 min. accumulation period per projection with 560 overlapping illuminations. We used the ptychographic reconstruction software provided at the P06 beam 


\section{WILEY-VCH}

line, implemented by Robert Hoppe. The tomographic reconstruction was done with MATLAB ${ }^{\circledR}$ code developed by Manuel Guizar-Sicairos. ${ }^{[28]}$

\section{Acknowledgements}

This work has received financial support from the European Commission as part of the Framework 7 ICT 2009 collaborative project ROTROT (grant no. 288565), Eurotech Universities Alliance project "Interface science for photovoltaics (ISPV)", European Research Infrastructure (SOPHIA) and European Energy Research Alliance (EERA) are acknowledged for the support. This work has also been supported by Danish National Research Foundation, the Villum Foundation's Young Investigator Programme (2nd round, project: Materials for Energy Production) and The Danish Council for Strategic Research (project WAPART, j.no. 11-116380). Partial financial support was also received from the Danish Council for Independent Research, Technology and Production Sciences (project nr. 11-116864), the Danish Ministry of Science, Innovation and Higher Education under a Sapere Aude Top Scientist grant (no. DFF - 1335-00037A) and an Elite Scientist grant (no. 11-116028). Travel support for the synchrotron experiments was provided through the DANSCATT grant from the Danish Council for Independent Research | Natural Science (no. 12-130893). We gratefully acknowledge Torben Kjær for technical assistance with construction of the R2R X-ray coater, and Markus Hösel for assistance with preparation of graphics for the figures.

\section{Author Contributions}

H. F. Dam and T. R. Andersen contributed equally to this work with activities spanning both the experimental work with roll coating and X-rays studies as well as writing parts of the 


\section{WILEY-VCH}

manuscript. K. T. S. Thydén prepared the sample excerpts for ptychography using FIB. M.

Helgesen and J. E. Carlé prepared the polymers. J. Reinhardt and E. B. L. Pedersen worked at the beam line for the ptychography experiments together with P. S. Jørgensen who also assisted with the data analysis. R. R. Søndergaard and M. Jørgensen prepared the Flextrode materials for this study and discussed the work with E. Bundgaard. F. C. Krebs also prepared the Flextrode and formulated many of the inks used in the study, including the $\mathrm{ZnO}$, and conceived the idea for the study together with J. W. Andreasen. J. W. Andreasen planned and participated in the R2R and ptychography X-ray experiments and analyzed the data. F. C. Krebs and J. W. Andreasen co-wrote the manuscript, which was proof read by all authors.

[1] T. R. Andersen, H. F. Dam, M. Hösel, M. Helgesen, J. E. Carlé, T. T. Larsen-Olsen, S. A. Gevorgyan, J. W. Andreasen, J. Adams, N. Li, F. Machui, G. D. Spyropoulos, T. Ameri, N. Lemaître, M. Legros, A. Scheel, D. Gaiser, K. Kreul, S. Berny, O. R. Lozman, S. Nordman, M. Välimäki, M. Vilkman, R. R. Søndergaard, M. Jørgensen, C. J. Brabec, F. C. Krebs, Energy Environ. Sci. 2014.

[2] P. Sommer-Larsen, M. Jørgensen, R. R. Søndergaard, M. Hösel, F. C. Krebs, Energy Technol. 2013, 1, 15.

[3] F. C. Krebs, M. Hösel, M. Corazza, B. Roth, M. V. Madsen, S. A. Gevorgyan, R. R. Søndergaard, D. Karg, M. Jørgensen, Energy Technol. 2013, 1, 378.

[4] Plasticphotovoltaics, www.plasticphotovoltaics.com 2013.

[5] M. Hösel, R. R. Søndergaard, M. Jørgensen, F. C. Krebs, Energy Technol. 2013, 1, 102.

[6] N. Espinosa, R. García-Valverde, A. Urbina, F. C. Krebs, Sol. Energy Mater. Sol. Cells 2011, 95, 1293.

[7] M. C. Scharber, N. S. Sariciftci, Prog. Polym. Sci. 2013, 38, 1929.

[8] Neuer Weltrekord für organische Solarzellen: Heliatek behauptet sich mit $12 \%$ Zelleffizienz als Technologieführer. Heliatek.

[9] J. You, L. Dou, K. Yoshimura, T. Kato, K. Ohya, T. Moriarty, K. Emery, C.-C. Chen, J. Gao, G. Li, Y. Yang, Nat. Commun. 2013, 4, 1446.

[10] J. You, C.-C. Chen, Z. Hong, K. Yoshimura, K. Ohya, R. Xu, S. Ye, J. Gao, G. Li, Y. Yang, Adv. Mater. 2013, 25, 3973.

[11] M. A. Green, K. Emery, Y. Hishikawa, W. Warta, E. D. Dunlop, Prog. Photovolt. Res. Appl. 2014, 22, 1.

[12] J. E. Carlé, M. Helgesen, M. V. Madsen, E. Bundgaard, F. C. Krebs, J. Mater. Chem. C 2014, 2, 1290.

[13] A. Hadipour, B. de Boer, J. Wildeman, F. B. Kooistra, J. C. Hummelen, M. G. R. Turbiez, M. M. Wienk, R. a. J. Janssen, P. W. M. Blom, Adv. Funct. Mater. 2006, 16, 1897.

[14] G. Dennler, M. C. Scharber, T. Ameri, P. Denk, K. Forberich, C. Waldauf, C. J. Brabec, Adv. Mater. 2008, 20, 579.

[15] G. Dennler, M. C. Scharber, C. J. Brabec, Adv. Mater. 2009, 21, 1323.

[16] N. Li, T. Stubhan, D. Baran, J. Min, H. Wang, T. Ameri, C. J. Brabec, Adv. Energy Mater. 2013, 3, 301. 


\section{WILEY-VCH}

[17] T. T. Larsen-Olsen, T. R. Andersen, B. Andreasen, A. P. L. Böttiger, E. Bundgaard, K. Norrman, J. W. Andreasen, M. Jørgensen, F. C. Krebs, Sol. Energy Mater. Sol. Cells 2012, 97, 43.

[18] T. R. Andersen, H. F. Dam, B. Andreasen, M. Hösel, M. V. Madsen, S. A. Gevorgyan, R. R. Søndergaard, M. Jørgensen, F. C. Krebs, Sol. Energy Mater. Sol. Cells.

[19] N. Li, D. Baran, K. Forberich, F. Machui, T. Ameri, M. Turbiez, M. Carrasco-Orozco, M. Drees, A. Facchetti, F. C. Krebs, C. J. Brabec, Energy Environ. Sci. 2013, 6, 3407.

[20] A. P. L. Böttiger, M. Jørgensen, A. Menzel, F. C. Krebs, J. W. Andreasen, J. Mater. Chem. 2012, 22, 22501.

[21] W. Hoppe, Acta Crystallogr. Sect. A 1969, 25, 495.

[22] W. Hoppe, G. Strube, Acta Crystallogr. Sect. A 1969, 25, 502.

[23] W. Hoppe, Acta Crystallogr. Sect. A 1969, 25, 508.

[24] J. M. Rodenburg, A. C. Hurst, A. G. Cullis, Ultramicroscopy 2007, 107, 227.

[25] J. M. Rodenburg, A. C. Hurst, A. G. Cullis, B. R. Dobson, F. Pfeiffer, O. Bunk, C. David, K. Jefimovs, I. Johnson, Phys. Rev. Lett. 2007, 98, 034801.

[26] J. M. Rodenburg, H. M. L. Faulkner, Appl. Phys. Lett. 2004, 85, 4795.

[27] M. Guizar-Sicairos, J. R. Fienup, Opt. Express 2008, 16, 7264.

[28] M. Guizar-Sicairos, A. Diaz, M. Holler, M. S. Lucas, A. Menzel, R. A. Wepf, O. Bunk, Opt. Express 2011, 19, 21345.

[29] M. Holler, A. Diaz, M. Guizar-Sicairos, P. Karvinen, E. Färm, E. Härkönen, M. Ritala, A. Menzel, J. Raabe, O. Bunk, Sci. Rep. 2014, 4.

[30] M. Esmaeili, J. B. Fløystad, A. Diaz, K. Høydalsvik, M. Guizar-Sicairos, J. W. Andreasen, D. W. Breiby, Macromolecules 2013, 46, 434.

[31] B. Chen, M. Guizar-Sicairos, G. Xiong, L. Shemilt, A. Diaz, J. Nutter, N. Burdet, S. Huo, J. Mancuso, A. Monteith, F. Vergeer, A. Burgess, I. Robinson, Sci. Rep. 2013, 3.

[32] A. Schropp, R. Hoppe, J. Patommel, D. Samberg, F. Seiboth, S. Stephan, G. Wellenreuther, G. Falkenberg, C. G. Schroer, Appl. Phys. Lett. 2012, 100, 253112.

[33] H. F. Dam, F. C. Krebs, Sol. Energy Mater. Sol. Cells 2012, 97, 191.

[34] J. E. Carlé, T. R. Andersen, M. Helgesen, E. Bundgaard, M. Jørgensen, F. C. Krebs, Sol. Energy Mater. Sol. Cells 2013, 108, 126.

[35] J. Hou, H. Y. Chen, S. Zhang, G. Li, Y. Yang, J. Am. Chem. Soc. 2008, 130, 16144.

[36] J. E. Carlé, M. Helgesen, M. V. Madsen, E. Bundgaard, F. C. Krebs, J. Mater. Chem. C 2013.

[37] O. Hagemann, M. Bjerring, N. C. Nielsen, F. C. Krebs, Sol. Energy Mater. Sol. Cells 2008, 92, 1327.

[38] A.-M. Petrascu, M. H. J. Koch, A. Gabriel, J. Macromol. Sci. Part B 1998, $37,463$.

[39] C. G. Schroer, O. Kurapova, J. Patommel, P. Boye, J. Feldkamp, B. Lengeler, M. Burghammer, C. Riekel, L. Vincze, A. van der Hart, M. Küchler, Appl. Phys. Lett. 2005, 87, 124103. 


\section{WILEY-VCH}

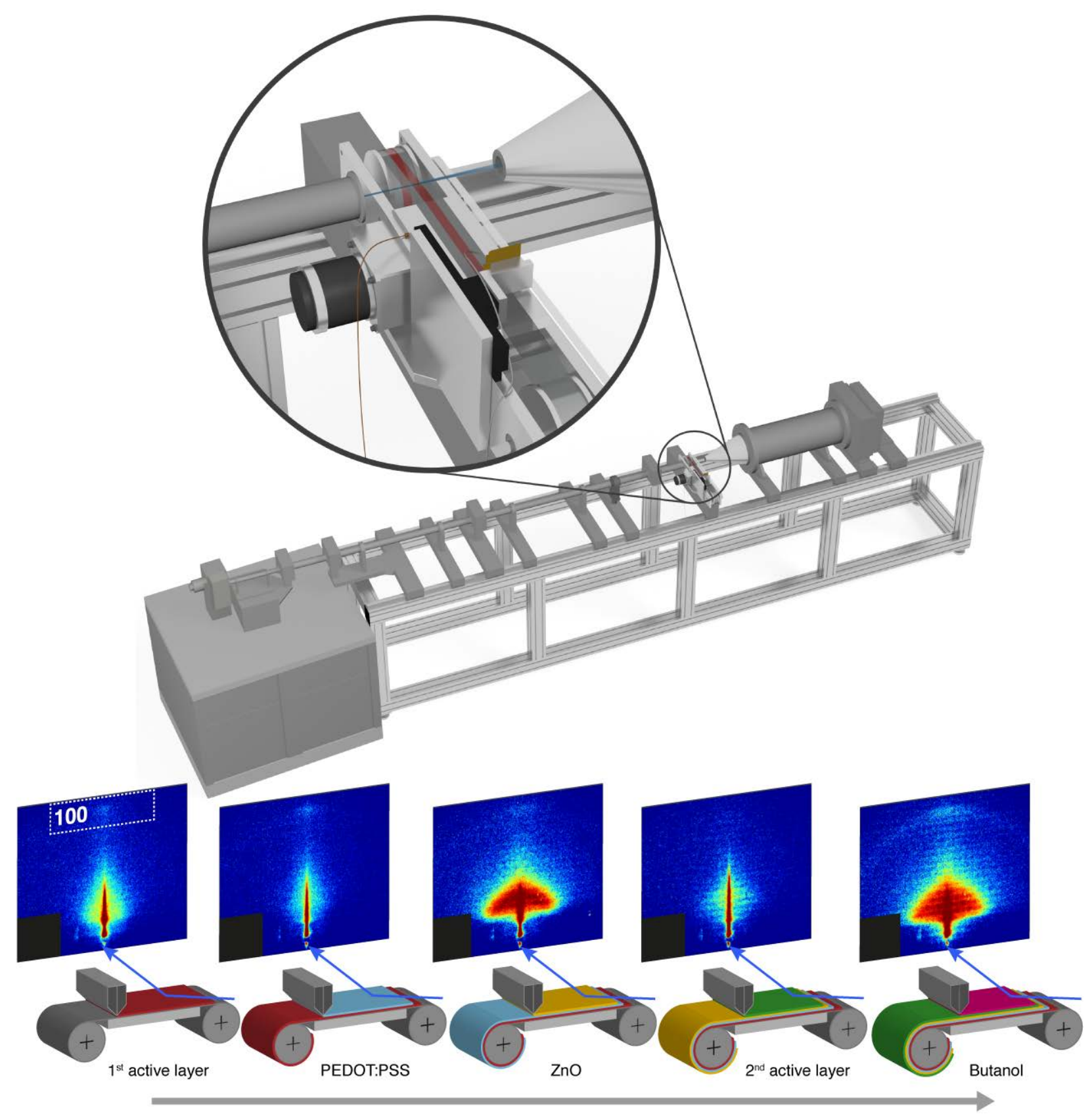

Figure 1 The R2R X-ray setup, about $6 \mathrm{~m}$ in overall length (top) with the small angle X-ray scattering data below, corresponding to coating of (from left to right): $1^{\text {st }}$ active layer, PEDOT:PSS and ZnO intermediate layers, $2^{\text {nd }}$ active layer and finally, a layer of butanol, testing the effect of a wet film that is not a solvent for the underlying layers. The position of the 100 reflection from P3HT corresponding to the lamellar stacking is marked in the scattering pattern of the $1^{\text {st }}$ active layer. 


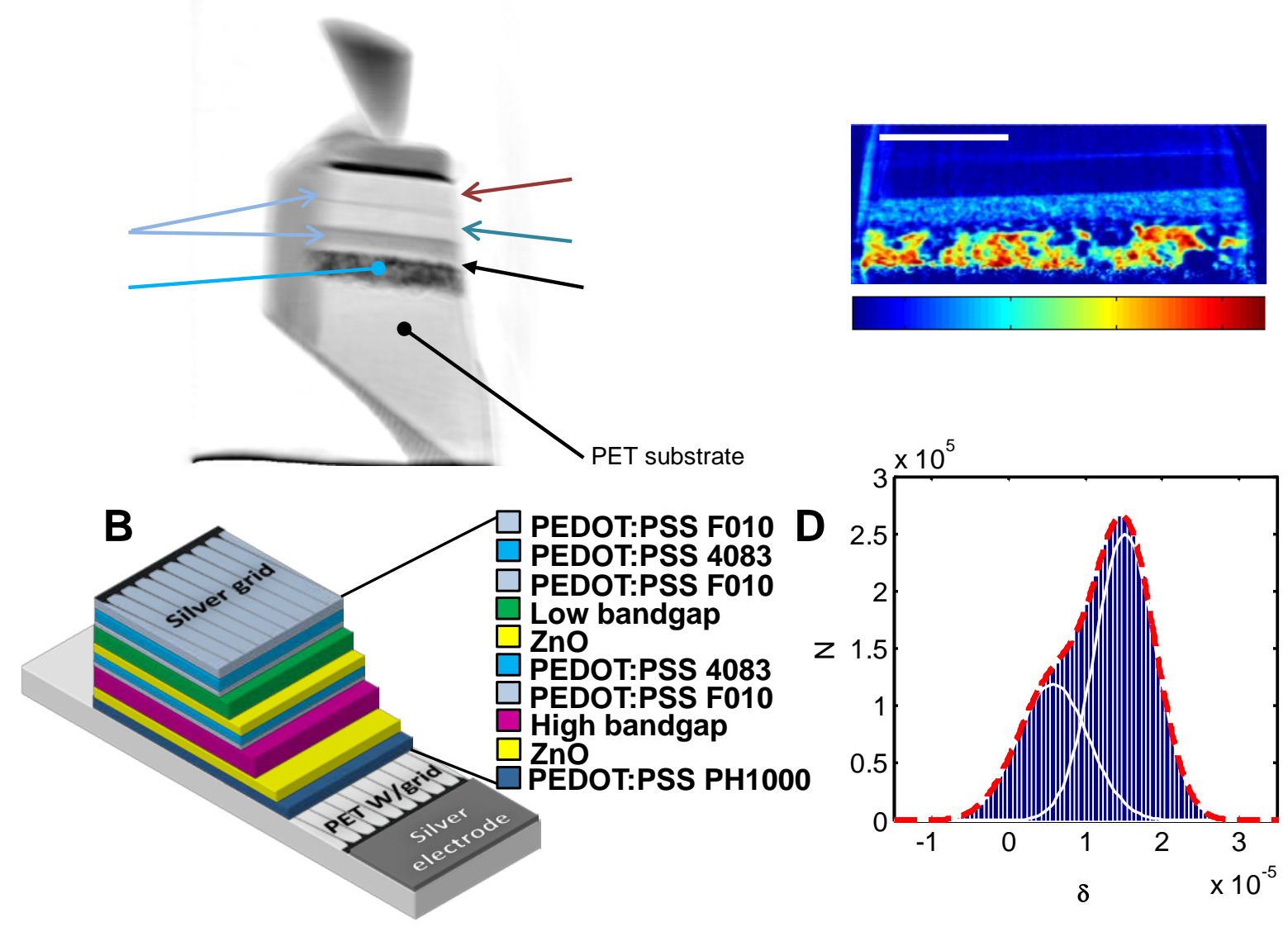

Figure 2 (A) Ptychographic phase contrast projection of the polymer tandem solar cell stack. (B) Schematic layout of the stack, showing the required layers for a full working cell. (C) Vertical slice through the 3D reconstruction of the real part of the X-ray refractive index showing the highly porous structure of the bottom silver electrode, with the well-defined overlying polymer and $\mathrm{ZnO}$ layers. The thin, faint line through the top part of the cell, is the trace of the $\mathrm{ZnO}$ recombination layer, less than $40 \mathrm{~nm}$ thick, but clearly defined. (D) Histogram of refractive indices in the reconstructed silver electrode volume fitted by two Gaussian functions corresponding to silver and PEDOT:PSS, showing the very high porosity with just $60 \%$ of the electrode volume occupied by solid silver. The void space is filled by matter with a refractive index that matches PEDOT:PSS. 
WILEY-VCH
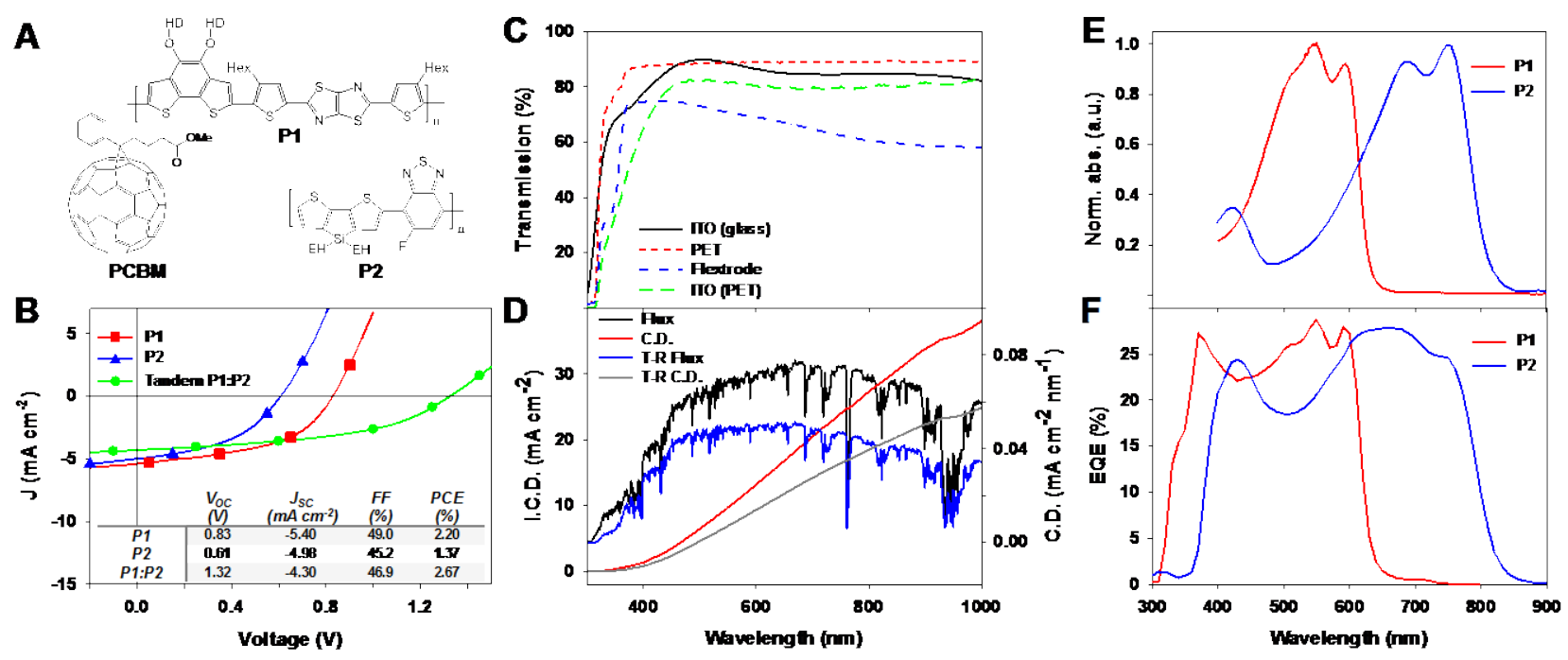

Figure 3 (A) Structure of the high and low band gap polymers P1 and P2 and PCBM (B) JV curves and performance numbers for reference cells of the two polymers and for the tandem cell produced from polymers P1 and P2. (C) Transmission measurements of different substrates, relative to air; ITO on glass, neat polyethylene terephthalate (PET) foil (Melinex $\left.{ }^{\circledR}\right)$, Flextrode on PET $\left(\right.$ Melinex $\left.{ }^{\circledR}\right)$ and ITO on PET, (Melinex $\left.{ }^{\circledR}\right)$. (D) Solar spectrum at AM1.5G (Flux) and solar spectrum convoluted with the transmission of the Flextrode substrate (T-R Flux). The integrated current densities (I.C.D.) for the AM1.5G spectrum (C.D.) and the Flextrode transmission reduced spectrum (T-R C.D). (E) Normalized absorption spectra of the polymers P1 and P2. The absorption spectra show the complementarity of the two polymers, indicating their suitability for tandem cells. (F) EQE measurement of devices prepared from $\mathbf{P 1}$ or $\mathbf{P} 2$ in a mixture with PCBM. 
Supplementary Information to the paper:

\section{Enabling Flexible Polymer Tandem Solar Cells by 3D Ptychographic}

\section{Imaging}

Henrik F. Dam, ${ }^{a}$ Thomas R. Andersen, ${ }^{a}$ Emil B. L. Pedersen, ${ }^{a}$ Karl T. S. Thydén, ${ }^{a}$ Martin

Helgesen, ${ }^{a}$ Jon E. Carlé, ${ }^{a}$ Peter S. Jørgensen, ${ }^{a}$ Juliane Reinhardt, ${ }^{b}$ Roar R. Søndergaard, ${ }^{a}$ Mikkel Jørgensen, ${ }^{a}$ Eva Bundgaard, ${ }^{a}$ Frederik C. Krebs, ${ }^{a}$ and Jens W. Andreasen ${ }^{a^{*}}$

Dr. H. F. Dam, Dr. T. R. Andersen, E. B. L. Pedersen, Dr. K. T. S. Thydén,Dr. M. Helgesen, Dr. J.

E. Carlé, Dr. P. S. Jørgensen, Dr. R. R. Søndergaard, Dr. M. Jørgensen, Dr. E. Bundgaard, Prof. F.

C. Krebs, Dr. J. W. Andreasen

Department of Energy Conversion and Storage, Technical University of Denmark, Frederiksborgvej 399, DK-4000 Roskilde, Denmark

Email : jewa@dtu.dk

J. Reinhardt

Deutsches Elektronen-Synchrotron DESY, D-22607 Hamburg, Germany 


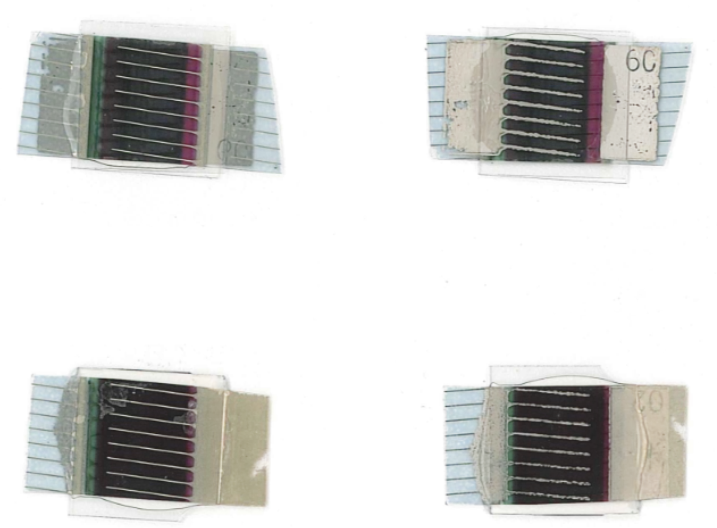

Figure Si1 : Images of typical tandem solar cells as reported in the paper. The four images shows two different cells, with the left images showing the cells from the front side, through which the light enters the cell, while the right set of pictures shows the back. The size of the cells vary from 0.8 to $1.0 \mathrm{~cm}^{2}$, depending on the overlap used for the individually coated layers and the position at which the cells are cut out. Data reported in this paper are from cells with a size of $0.85+-0.05$ $\mathrm{cm}^{2}$.

Coating report for the tandem cells, including speed, temperature, wet thickness and estimated dry thickness of the coated films.

Table Si1 : Parameters used for coating of the individual layers of the tandem cells.

\begin{tabular}{|l|l|l|l|l|l|l|}
\hline Layer & Material & Concentration & Speed & Flow & $\mathrm{T}_{\text {wet }}$ & $\mathrm{T}_{\text {dry }}$ \\
\hline Substrate & Flextrode & & & & & Estimated \\
\hline 1st active layer & P1 & $10.0 \mathrm{mg} / \mathrm{ml}$ & $\begin{array}{l}1.30 \\
\mathrm{~m} / \mathrm{min}\end{array}$ & $\begin{array}{l}0.170 \\
\mathrm{ml} / \mathrm{min}\end{array}$ & $13 \mu \mathrm{m}$ & $150 \mathrm{~nm}$ \\
\hline $\begin{array}{l}\text { Compatibilizer } \\
\text { layer }\end{array}$ & $\begin{array}{l}\text { Pedot } \\
\text { F010:IPA }\end{array}$ & $80.0 \mathrm{mg} / \mathrm{ml}$ & $\begin{array}{l}1.30 \\
\mathrm{~m} / \mathrm{min}\end{array}$ & $0.10 \mathrm{ml} / \mathrm{min}$ & $8 \mu \mathrm{m}$ & $20 \mathrm{~nm}$ \\
\hline $\begin{array}{l}\text { Hole Transport } \\
\text { layer }\end{array}$ & $\begin{array}{l}\text { Pedot } \\
\text { 4083:IPA }\end{array}$ & $20 \%$ & $\begin{array}{l}1.30 \\
\mathrm{~m} / \mathrm{min}\end{array}$ & $0.3 \mathrm{ml} / \mathrm{min}$ & $23 \mu \mathrm{m}$ & $75 \mathrm{~nm}$ \\
\hline $\begin{array}{l}\text { Electron } \\
\text { Transport }\end{array}$ & ZnO & & $\begin{array}{l}2.0 \\
\mathrm{~m} / \mathrm{min}\end{array}$ & $0.10 \mathrm{ml} / \mathrm{min}$ & $5 \mu \mathrm{m}$ & $55 \mathrm{~nm}$ \\
\hline $\begin{array}{l}\text { 2nd active layer } \\
\text { P2 }\end{array}$ & $12.0 \mathrm{mg} / \mathrm{ml}$ & $\begin{array}{l}1.30 \\
\mathrm{~m} / \mathrm{min}\end{array}$ & $\begin{array}{l}0.190 \\
\mathrm{ml} / \mathrm{min}\end{array}$ & $15 \mu \mathrm{m}$ & $220 \mathrm{~nm}$ \\
\hline $\begin{array}{l}\text { Compatibilizer } \\
\text { layer }\end{array}$ & $\begin{array}{l}\text { Pedot } \\
\text { F010:IPA }\end{array}$ & $20 \%$ & $\begin{array}{l}1.30 \\
\mathrm{~m} / \mathrm{min}\end{array}$ & $0.10 \mathrm{ml} / \mathrm{min}$ & $8 \mu \mathrm{m}$ & $20 \mathrm{~nm}$ \\
\hline $\begin{array}{l}\text { Hole Transport } \\
\text { layer }\end{array}$ & $\begin{array}{l}\text { Pedot } \\
\text { 4083:IPA }\end{array}$ & $33 \%$ & $\begin{array}{l}1.30 \\
\mathrm{~m} / \mathrm{min}\end{array}$ & $0.3 \mathrm{ml} / \mathrm{min}$ & $23 \mu \mathrm{m}$ & $75 \mathrm{~nm}$ \\
\hline $\begin{array}{l}\text { Conducting } \\
\text { Layer }\end{array}$ & $\begin{array}{l}\text { Pedot } \\
\text { F010:IPA }\end{array}$ & $50 \%$ & $\begin{array}{l}1.30 \\
\mathrm{~m} / \mathrm{min}\end{array}$ & $0.50 \mathrm{ml} / \mathrm{min}$ & $38 \mu \mathrm{m}$ & $288 \mathrm{~nm}$ \\
\hline Top Electrode & Ag PV410 & & & & & \\
\hline
\end{tabular}

